\title{
The Livestock Sub-Sector in the Third National Development Plan
}

\author{
By \\ Professor Akin. Ademosun \\ Dean, Faculty of Agriculture \\ University of Ife
}

\section{INTRODUCTION}

NUTRITIONISTS, livestock production experts, social workers, home economists and a host of other professionals have expressed grave concern at the very low level of animal protein intake by Nigerians particularly among rural communities, which constitute about $80 \%$ of the Nigerian population, and the low income group generally. Intake figures representing about a quarter of the requirement have been reported while data from countries like U.K., U.S.A. Denmark and New Zealand indicate animal protein consumption about ten times that in Nigeria. While, it is true that consumption data available in Nigeria might not include meat from sources such as wild animals fotherwise referred to as "bushmeat"), domestic, animals such as dogs, donkeys, cats rabbits and guinea pigs and other animals such as rats and bats; it is also true that even when adequate allowances have been made for these other resources, animal protein intake of the people is still grossly inadequate. One must also recognize that in addition to the role of livestock as source of animal protein, their products such as hides and skins are foreign exchange earners and also provide leather for local industries. Animal power is a potential source of farm mechanisation particularly in the savannah areas of the country. It has been estimated that annual gross output of Nigerian livestock at producer prices is about 170 million and at retail values about 250 million. Thus, livestock production represents a major national investment with important economic, nutritional and social implications for the country(1). For these reasons therefore, there is need for the livestock industry in Nigeria to be developed.
Although there are no accurate data on the actual numbers of the different species of livestock in Nigeria, and different "guestimates" have been used, it is generally believed that the various types of livestock in Nigeria present an attractive potential for improved production. Government has accordingly set out the objectives of the livestock production programmes in Nigeria as follows(2):

(a) to be self-sufficient in the supply of meat and other livestock products so as to save foreign exchange,

(b) to improve rural incomes,

(c) to provide rural employment opportunities,

(d) to improve human nutrition,

(e) to effect proper land use and maintain the ecosystem.

To achieve these objectives the governments of the Federation have provided for an expenditure of $\$ 344.05$ million on the livestock sub-sector during the current Third National Development Plan period. This represents $15.6 \%$ of the total provision for the agricultural sector. For comparison, other sub-sectors have the following percentage allocations:

$\begin{array}{cc}\text { Agriculture (Crops) } & 74.8 \% \\ \text { Forestry } & 5.0 \% \\ \text { Fisheries } & 4.6 \%\end{array}$

For a further comparison, only $9.1 \%$ out of a total provision of over $\ 265$ million for the agricultural sector was made to livestock during the Second National Development Plan period. The percentage allocations to other sub-sectors during the Second Plan period were: Agriculture (crops) $81.3 \%$, Forestry $5.0 \%$, Fisheries $4.6 \%$. One can thus see that not only has there been nearly a fifteen fold increase in the provision for the livestock sub-sector in the Third Plan period as compared to 
the Second Plan period, there has been an increase in the percentage provision for livestock as compared with other subsectors. Impressive as these figures appear, it is distressing to note that with an estimated human population of 80 million in 1980 the projected meat supply by 1980 will only allow for a daily per capita consumption of $5.7 \mathrm{~g}$ of meat per day. This is not an improvement over the situation as at now although one must also note that fish, milk and milk products as well as eggs also contribute to animal protein intake. The reason for this low response to heavy investment in terms of percapita meat availability is the rapid growth in human population as compared to livestock population. For instance, the Plan envisages a $1.5 \%$ per annum increase in cattle population as against a $2.5 \%$ per annum increase in human population. Also there will be an increase in the off-take of cattle from $7.8 \%$ to $9.0 \%$ while carcass weight will increase from $170 \mathrm{~kg}$ to $180 \mathrm{~kg}$. There are no increases in the percent offtake for other species of livestock while projected population increases for them are minimal.

I shall now comment briefly on various aspects of the Plan.

\section{Cattle Production}

Government policy with regards to cattle production during the Plan period is to:

(a) abolish jangali (cattle tax).

(b) settle the normadic herdmen by the creation of grazing reserves and relosation of the national herd,

(c) improve beef cattle production through:
(i) establishment of national breeding centres,
(ii) provision of artificial insemina- tion services,
(iii) adoption of a "block system" in artificial insemination ser- vices,
(iv) tse-tse fily eradication,
(v) encouragement of commercial livestock production,
(vi) introduction of trypano-tole- rant breeds and
(vii) establishment of livestock feed company.

(d) Government will also participate in direct production of beef and dairy cattle.

With the abolition of jangali, which has already been accomplished, one hopes that it will now be possible to obtain more reliable livestock census data, that mutual confidence will be restored between the Fulani herdsmen and livestock officers and that the sale of cattle just to pay taxes will be on the decrease. Lack of adequate grazing land for most of the year in the Sudano-Sahelian zone, where most of the national herd is located, has led government to propose, the relocation of the national herd and the establishment of grazing reserves. Both of the programmes will cost government over $\$ 40$ million during the Plan period. The objectives and advantages of these programmes have been discussed elsewhere( 3 ). With the ambitious tse-tse eradication programme proposed, I am strengthened in my belief that the central region of Nigeria holds more potential for ruminant livestock development than any other region. Even with the tsetse fly, trypano-tolerant breeds of beef animals such as the N'dama and Keteku, which have been successfully kept in the derived savannàh region for several decades now, can be raised. Also chemotherapy against trypanosomiasis can be employed. The central region has a rainfall of between 1,000 and 1,500mm per year leading to the availability of a highly productive natural grassland. There is a potential for the further improvement of this natural grassland for efficient utilization by livestock. Being central, the location of a substantial proportion of the national herd in this region will encourage a more efficient marketing and distribution system for livestock than the present system. Most of the cattle transported from the far north to the south are transported on the hoof while about equal numbers are transported by truck and by rail. Because of the long distance involved and because of the poor road and rail system in Nigeria, costs incurred include salvage and shrinkage losses, high drivers' fees or freight costs, exposure to diseases, injuries and parasites, starvation and lack of water and losses due to accidents on the roads. 
The proposal to establish a livestock feed company which will use agricultural by-products for the production of high quality feeds is laudable in principle: but when one takes a look at the performance of our public companies, corporations and other quasi-government establishments in this country, one is apt to become sceptical about the prospects of the company. Because of the unduly heavy overheads and the bureaucracy to which these establishments have been subjected, very many of them have failed in this country. In a few cases. their names and laws have been changed to no avail. All one can say here is that a close look should be taken at these establishments, and, in setting up the feed company, steps will be taken to avoid past mistakes. Already Worid Bank loan has been taken to establish beef ranches in certain parts of Nigeria and Boards of Directors of Companies set up to implement Federal government intention to cooperate with some State governments in the direct production of cattle through the establishment of ranches. Again this is a laudable programme since the establishment of ranches is a very expensive undertaking and cannot now be left to the private sector. The same thing is true of dairy production but even now in the north large quantities of milk are wasted annually because of an inefficient collection system and poor processing by the herdsmen. The normadic system itself does not lend itself to an efficient system of milk collection and it is hoped that with the programmes of relocating the national herd and the establishment of grazing reserves, milk collection centres will be established so that milk can be collected promptly and processed.

\section{Sheep and Goat Production}

Sheep and goats contribute about $30 \%$ of the total meat consumed in Nigeria and the demand for goat meat and mutton is rising. They produce valuable skins for both export and the local leather industry. The Federal Government admits that "although the demand for sheep and goats has been increasing rapidly in the past years, the modernization of the industry has however been neglected. It is on this account that the Federal Government will carry out feasibility studies on the establishment of four breeding and fattening centres in the Federation" (1). The total direct provision for sheep and goat production by all governments is about $\$ 9.5$ million during the Plan period. This is inadequate judged by the contribution of these species to food consumption locally and to foreign exchange earning. It is also my considered opinion that, as far as these animals are concerned we have gone beyond the stage of feasibility studies on the establishment of breeding and fattening centres in this country. In the early sixties improved stock of the Red Sokoto goat was developed by selection at the Bulassa Livestock Investigation and Breeding Centre and at the Kwotor $\mathrm{K}$ washi Livestock Investigation and Breeding Centre both in Sokoto state. Improved male animals from these Centres were distributed to farmers. The programme was described as successful(4). At the Katsina Livestock Investigation and Breeding Centre in Kaduna State, work in the late fifties and early sixties showed that although the pure Merino sheep might not do well in Nigeria the Black Headed Persian offers potential. Early results from studies at this Centre showed that crosses of the Merino and the Black Headed Persian with the local breeds of Y'ankasa and Ouda resulted in improved performance and carcass quality of the local breeds. Reports from the University of Ife have shown that the growth performance of the West African Dwarf goat can be improved by crossing with imported Saanen goat(5) while at the University of Ibadan. the West African Dwarf sheep has been studied under improved management conditions (6).

I have used these few examples to establish that as far as sheep and goats are concerned we have gone past the stage of feasibility studies in this country and that judged by the contribution of these two species of animals to animal protein consumption and foreign exchange earning, the provision for their improvement in the Third National Develop- 
ment Plan is inadequate. One could have liked to see a programme aimed at the establishment, by Federal and State governments, of breeding and improvement centres for the selection of local breeds for crossing with adaptable imported breeds. These centres can also serve as demonstration centres and the source of improved genetic material for local farmers. A substantial investment in this programme, backed up by good livestock extension service, will yield faster results than an equal investment in cattle production.

\section{Pig, Poultry and Rabbit Production}

These non-ruminant animals offer the avenue for the most rapid transformation in animal protein production in this country. This is because there is a greater turn over rate, less land is required and the buildings and other facilities can be simpler and cheaper than for ruminants. Rabbits have the added advantage that a substantial part of the feed can be provided by herbage crops and weeds. Rabbit meat is not well liked by some people but what is required is good extension service by livestock men and home economists.
There has been practically no work done on these other species. Limited studies at the University of Ife, where the guinea fowl has been compared with Rhode Island Red and White Leghorn chickens, have shown that egg shell quality as measured by shell weight per unit area is much higher for the guinea fowl while the weight of the egg shell of the guinea fowl is higher than that of the two breeds of domestic fowl although the reverse was true with regards to egg weight (table 1).

For pigs and poultry, we still have to depend on importation for the supply of foundation stock while feed costs have seriously limited production. These are areas that need the urgent attention of government if the advantages inherent in the production of these non-ruminant animals are to be fully derived. A mere provision of only about $8 \%$ of the total estimated expenditure for the livestock sub-sector directly to pig and poultry is grossly inadequate when it is realised that these animals contribute over $25 \%$ of the local meat production in this country. At the end of the Plan period the projected contribution of pigs and poultry to local meat production is estimated at $29 \%$.

TABI.F. 1

Some characteristics of the of the guinea fowl as compared with that of the domestic fowl

\begin{tabular}{lccc} 
& Guinea fowl & Rhode Island Red & White Leg-horn \\
Hen & Hen & 53.7 \\
Egg weight $(\mathrm{g})$ & 36.3 & 54.6 & 4.8 \\
Egg shell weight $(\mathrm{g})$ & 5.1 & 6.4 & 72.7 \\
Shell weight per unit area of surface $\left(\mathrm{mg} / \mathrm{cm}^{2}\right)$ & 93.6 & 6.2 & \\
\hline
\end{tabular}

While commercial poultry production is sufficiently advanced to be left in the hands of private farmers, it must be realised that infrastructural support such as supply of improved genetic material, livestock extension and good marketing and distribution channels for poultry products must be provided in order to reduce the cost of production and exploitation by unscrupulous middlemen. Other poultry species such as turkeys, guinea fowls, ducks and geese deserve more attention than they have received so far.

\section{Livestock Research}

I have only recently(3) criticized the Research Institutes (Establishments etc.) Order of 1975 for two main reasons:

(i) Only one out of 14 Research Institutes is directly concerned with animal production research although there are two concerned with disease control and one with animal products.

(ii) This one Animal Production Research Institute is under the cont. rol of a University while all the 
other thirteen Research Institutes are under the direct control of the Agricultural Research Council of Nigeria.

It is inconceivable that one Research Institute, tied to the apron strings of a University, can adequately cope with Animal Production Research. This is why I must once again urge the Federal Commissioner for Agriculture and Rural Development to give urgent consideration to the review of this Order and to establish five Research Institutes in addition to the ones already established which are concerned with animal disease control (that is; Nigerian Institute for Trypanosomiasis Research which is concerned with trypanosomiasis control and the National Veterinary Research Institute which is concerned with the control of animal diseases generally and the production of vaccines). These five Research Institutes are:

(1) The Animal Products Research Institute of Nigeria which will perform the present functions of the Leather Research Institute of Nigeria as well as be involved in research in dairying and meat technology.

(2) The Poultry Research Institute of Nigeria to be involved in research into the production of the domestic fowl, guinea fowl, ducks, geese and turkeys.

(3) The Animal Production Research Institute of Nigeria to be concerned with research into cattle, sheep and goat production.

(4) The National Institute for Research in Pig Production to be involved in pig and rabbit production as well as to be concerned with the standardization and quality control of manufactured animal feeds.

(5) The Grassland Research Institute of Nigeria to be concerned with research into the productivity, nutritive value and improvement of Nigeria's vast natural grassland and improved pastures.
Each of the Research Institutes concerned with the different animal species will be involved in research in climatology, environmental and reproductive physiology, livestock shelters, nutrition, breeding and selection, economics of livestocks production and socio-economic problems as well as the control of specific diseases. $A / /$ the Research Institutes MUST operate under the contral of the Agricultural Research Council of Nigeria.

\section{The Role of The Nigerian Livestock and Meat Authority}

The Livestock and Meat Authority was originally established to serve the Northern States and it has only recently assumed national status when it was charged with collecting and collating datit, conducting surveys and research into various aspects of livestock production, slaughter and marketing in Nigeria. To achieve these objectives the Authority will spend over N60 million during the development Plan period. As to be expected, the largest cxpenditure is on the establishment of new or expansion of existing cattle ranches and construction of abattoirs and meat markets. There is a provision of only 14,000 for "rabbit industry" without a description of what is intended to be achieved. While there is a total provision of $\mathrm{N} 3.6$ million for the establishnent of Poultry Production and Breeding Units, the Authority plans for an expenditure of $\$ 2.25 \mathrm{~m}$. on a pig project at Mokwa. One of the major functions of the Authority is the provision of market information and effective publicity service to ensure livestock production along the right lines as well as to encourage the ccnsumption of livestock products. Provision of 290.000 to establish state information offices as well as a Market Research and Economic Unit and promotional publicity and advertisement is grossly inadequate. The quarterly Market Information Service produced by the Authority at present is usually about a year late, contains scanty information and does not cover the whole country. This is why the Authority needs to invest more on Market Research and a communication system that will provide useful and country wide information promptly. 


\section{The Role of the Federal Livestock Department}

The four development departments of the Federal Ministry of Agriculture and Natura! Resources were created at the end of 1969. The Federal Livestock Department is responsible for co-ordinating and stimulating the development of the livestock industry, advising the Federal Government on policy matters in consultation with other State and Federal organisations responsible for Iivestock matters as well as carrying out certain functions that cut across State and National boundaries(7). Also as a result of the re-organisation of the Federal Ministry, the National Council for Agriculture and Natural Resources was created which in turn set up four development committees on Agriculture, Fishcries, Livestock and Forestry. The composition of the National Livestock Development Committee is as follows:

The Director, Federal Livestock Department $\quad . . \quad . . \quad \ldots$ Chairman

The Chief Veterinary Officer of each State in the Federation .. Member

The Officer in charge of Animal Husbandry of those States where it is not under the Chief Veterinary Officer ... .. . Member

The Director, Federal Department of Veterinary Research .. Member

The Director, Nigerian Institute of Trypanosomiasis Research. Member

The Chief Veterinary Tsetse Officer (Federal) $\quad . \quad \ldots \quad . . \quad$ Member

The Chief Veterinary Officer (Federal) .. .. .. Member

The Deans of Veterinary Faculties in the Federation .. .. Member

The General Manager, Nigerian Livestock and Meat Authority Mcmber

The Chief Livestock Planning Officer (Federal) $\quad . \quad \ldots \quad . \quad$ Secretary

This committee took over from the Veterinary Technical Committee. Whereas a membership list as stated above might have sufficed for a Veterinary Technical Committec one expects that for a Livestock Development Committee, to be effective in its job of advising government on technical livestock development it should be composed, as much as possible, of professionals in all aspects of livestock production. To the extent that the present composition of the National Livestock Development Committee does not represent all professional groups that are competent to advise on livestock development, the Committee cannot be expected to be very effective in this role. I am therefore calling on the appropriate Federal Government agency to review the composition of the National Livestock Development Committee to reflect a balance among the following professional groups:-

Animal husbandry experts

Animal Breeders and Geneticists

Reproductive and Environmental physiologists

Animal Nutritionists

Veterinarians

Grassland Agronomists and Range

Management experts

Meat Technologists

The membership should also include at least one farmer involved in commercial livestock production.

The tse-tse extermination programme of the Federal Livestock Department receives a major attention in the Plan and it is estimated that on the implementation of the programme about $28 \%$ of Nigeria's land area will be tsetse free. The development of grazing reserves and the relocation of the national herd are also programmes with which the Department will be concerned during the Plan period. However in order for the Department to be able to effectively coordinate and stimulate livestock development all over the country it needs well established State offices where staff work in close cooperation with their state counterparts and serve as a link between the Department and the State governments. This is the method that the Federal Department of Agriculture has used for effective communication between it and state officials.

\section{The Role of the State Governments}

The total estimated state government expenditure during the Plan period is about equal to that of the Federal govern- 
ment. There is an overlap in the Federal and State government programmes such as the expansion of existing and creation of new ranches, establishment of feed companies, establishment of multiplication and breeding centres, disease control programmes etc. This is desirable but one expects that there will be adequate coordination of programmes. The focus for this coordination should be at the Federal Livestock Department and for marketing, publicity and to some extent production, the Nigerian Livestock and Meat Authority should coordinate State and Federal activities. With regards to research, the Agricultural Research Council of Nigeria, in cooperation with the Universities, should be responsible coordinating research efforts. One sad aspect of livestock research in Nigeria is that whatever little that has been done up to now has not really got to the farmers as much as one would expect. This is due to a grossly inadequate or sometimes non-existent livestock extension service. The state governments with Federal government assistance must be responsible for livestock extension. One of the problems here is manpower shortage. It is a sad reflection on a country with the potential that Nigeria has, that we can admit that "the difficulties that were encountered in the implementation of projects in the Second Plan period, made it clear that a general shortage of qualified personnel has become a major constraint to agricultural development" (1). Yet graduates in agriculture end up teaching basic sciences in the high schools, others find it difficult to obtain jobs for months after the Youth Corp Service programme. This situation calls for prompt action by State governments. Ministries of Establishment must be persuaded to increase recruitment of professionals into our Ministries of Agriculture.

Rural-urban migration will continue in this country as long as the quality of life in the rural areas is sub-standard. Yet the country must continue to depend on the rural areas for agricultural production because about $80 \%$ of the Nigeria population live in rural communities: over $90 \%$ of those who live in the rural areas are engaged in agricultural produc- tion while nearly all of the farm operation depend on human labour. One of the objectives of the agricultural programmes in this Plan period is to create rural employment opportunities to absorb more of the increasing labour force in the nation and to stem the tide of ruralurban migration(3). Without massive investment in infra-structure development in the rural areas, we cannot stem the tide of rural-urban migration. The state government must increase the pace of the programmes aimed at the improvement of the quality of life in the rural areas.

\section{CONCLUSION}

The livestock sub-sector of the Nigerian economy represents an area where rapid transformation is expected in order to improve the quality of our foods, earn more foreign exchange and safeguard a major national investment. The provision for the sub-sector during the Third National Development Plan period represents a marked improvement over the provision during the Second National Development Plan period. Cattle production continues to enjoy the pride of place although it is rather unfortunate that greater attention is not paid to the smaller animals particularly the nonruminants where more rapid transfor mation can be expected. Both the Nigerian Livestock and Meat Authority and the Federal Livestock Department must work more closely with State governments in order to be able to play their roles more effectively. The composition of the National Livestock Development Committee needs to be more broad-based professionally in order to be objective in coordinating and stimulating the development of the livestock industry and advising the Federal government on policy matters.

The proposed National Animal Production Research Institute of Nigeria will be inadequate to cope with all aspects of animal production research in this country. More research institutes are needed to effectively cover the different species of livestock as well as animal products and grassland research. The State governments, in addition to their 
various animal production programmes during the Plan period, should be more involved in manpower development and provision of needed infrastructure in the rural areas.

The Third National Development Plan, should be subjected to constant project performance review and modifications in the light of experience and particularly because of the recent creation of new States in the country.

\section{REFERENCES}

Third National Development Plan 1975-80. Federal Republic of Nigeria, Lagos.

David-West, K.B. 1975. Planning the agricultural Projects and programmes - Livestock sector. Paper presented at the Workshop on the Ecological Implications of the Projects in the Agricultural Sector of the Third National Development Plan.

Ademosun, A.A. 1976. Livestock Production in Nigeria-Our Commissions and Omissions. University of Ife Inaugural Lecture series No. 17.

Ferguson, W. 1964. The development of Sheep and Goat production in the Northern Region of Nigeria. Proc. 1st FAO African Regional Meeting on Arimal Production and Health. Ethiopia.

Ademosun, A.A. 1973. The development of the Livestock Industry in Nigeria-Ruminants. Proc. Niger. Agric. Soc. 10: 13-20

Dettmers, Almut and Looslu. J. K. 1974. Live performance and carcass traits in West African Sheep. Proc. Niger. Soc. Animal Prod. 1: 108

Federal Jivestock Department Report 1970-1974. Federal Ministry of Agriculture and Rural Development. Kaduna. 